\title{
THE RELATIONSHIP OF HEALTHY LIFESTYLE INDEX (HLI) TO THE OCCURRENCE OF HYPERTENSION IN MOUNTAINS, COASTAL, AND URBAN COMMUNITIES
}

\author{
Iis Noventi ${ }^{1 *}$, Yanis Kartini ${ }^{1}$ \\ ${ }^{1}$ Faculty of Nursing and Midwifery, Nahdlatul Ulama University, Surabaya \\ *Correspondence: \\ Iis Noventi \\ Email: iisnoventi@unusa@ac.id \\ Address: Faculty of Nursing and Midwifery, Nahdlatul Ulama University, Surabaya, Jl. SMEA No. 57 Surabaya
}

\begin{abstract}
Background: Epidemiological transitions cause changes in disease trends from transmitted diseases to non-communicable diseases. One disease that continues to increase in prevalence and have a high-risk complication, namely hypertension. This disease has key risk factor namely lifestyle. The role of lifestyle on the incidence of hypertension is very close, especially in the community city. Surabaya has the highest prevalence of hypertension in Indonesia but has a prevalence and the role of lifestyle to the coastal and mountainous regions has not been studied so has not it is known whether hypertension is only concentrated in urban areas or also has an impact for coastal and mountainous regions.

Objective: The purpose of this study was to examine relationship between the Healthy Lifestyle Index score to the occurrence of hypertension in mountainous, coastal, and urban communities.

Method: This study was a cross sectional observational study. The samples in this study were 30 people in the coastal community, 30 people in the mountain community and 30 people in the urban community. All of respondents visiting the Supporting Public Health Center of Gili Ketapang, Supporting Public Health Center of Wonotoro, and Public Health Center of Kebonsari. Lifestyle assessment use the Tube version of Healthy Lifestyle Index (HLI) (2015) which consists of domains quality of the diet, physical activity, smoking behavior, and BMI. Data analysis uses statistical tests chi square test to determine the relationship HLI scores with the incidence of hypertension. Result: The relationship of HLI scores with the incidence of hypertension in mountainous communities, hypertension caused by smoking, while hypertension in coastal communities is caused because of eating patterns and lack of activity, hypertension in urban communities is caused due to unhealthy eating patterns, smoking, lack of activity and obesity.

Conclusion: There is a significant relationship between the Healthy Lifestyle Index score with the incidence of hypertension in mountainous, coastal and urban areas.
\end{abstract}

Key words: Lifestyle, Hypertension, Mountains, Urban, Coastal.

\section{INTRODUCTION}

Hypertension is a disease characterized by high blood pressure above normal and is permanent. This disease is one of the health problems in Indonesia and in the world. Hypertension is often referred to as the silent killer because the condition experienced by sufferers is generally asymptomatic and then only has meaning when it reaches a level of severe damage. Hypertension has several factors that can be a risk for hypertension, such as family history, smoking habits, eating habits of fatty foods, lack of physical activity, and high sodium intake.

World Health Organization (WHO) data in 2008 shows that the prevalence of hypertension in adults aged $\geq 25$ years in 
the world is around $38.4 \%$. The data also showed that the prevalence of hypertension in Southeast Asia reached 36.6\%. Indonesia is the country with the second highest prevalence of hypertension after Myanmar to Southeast Asia, which is around $41 \%$ (WHO, 2013). Riskesdas data 2013 showed that around 25.8 percent of Indonesia's population had hypertension. In 2016, the National Health Indicators Survey (Sirkesnas) mentioned an increase the percentage of the population with hypertension is 32.4 percent. The trend of hypertension cases continues to increase from year to year in line with the transition epidemiology. Based on WHO data, an increase of 400 cases is known from 1980 to 2008 and it is predicted that hypertension cases will reach 1.56 billion in 2025 (WHO, 2011). From the data provided by the Ministry of Health, Hypertension being the first ranked non-communicable disease diagnosed at a health facility, with the number of cases reached 185,857. This figure is almost 4 times more than disease type 2 diabetes mellitus is ranked second. High prevalence rates the need for preventive efforts to avoid the public, especially those who have shown early symptoms of hypertension so that complications do not occur. In Indonesia there are many it is estimated that 15 million people suffer from hypertension but only $4 \%$ are hypertensive controlled. Prevalence is $6-15 \%$ in adults, $50 \%$ of whom are unaware as people with hypertension so they tend to become severe hypertension because they don't avoid and do not know the risk factors, DNA 905 is essential hypertension (Saputra \& Anam, 2016). Hypertension often causes no symptoms, while blood does persistently high in the long run can cause complications. Therefore, hypertension needs to be detected early, namely by checking blood pressure regularly (Arif, Rusnoto, \& Hartinah, 2013). According to Arif, Rusnoto, \& Hartinah (2013), factors that influence hypertension divided into two major groups, namely inherent or irreversible factors such as type of sex, age, genetics and factors that can be changed such as diet, exercise habits and others. For the occurrence of hypertension need the role of these risk factors together (common underlying risk factor) in other words, one risk factor is not enough cause hypertension. Hypertension occurs due to behavioral and habitual factors life, these factors are diet, physical activity, smoking habits, consumption alcohol, and body mass index. Instruments that are often used to assess the quality of style life is the Healthy Lifestyle Index (HLI). HLI is a health assessment tool easy to use and allows people to measure the quality of the latest lifestyle like body mass index, diet quality, smoking history, alcohol consumption, and physical activity.

Urbanization and globalization are indirect causes of increasing prevalence hypertension (Peer, et al., 2013). Some studies say that both of them are a factor in the difference in the prevalence of hypertension in urban and rural areas (Addo et al., 2007; Bokhour, et al., 2012; Hou, 2008; Musinguzi and Nuwaha, 2013; Perkovic, et al., 2007). The results of the Riskesdas (Balitbang Kemenkes RI, 2013) also showed that the prevalence of hypertension urban is greater than rural, which is $26.1 \%$ in urban and $25.5 \%$ in rural. Whereas the study of Sundari et al in 2013 showed the prevalence of hypertension in the regions the coast is higher than in the mountains. This is related to high sodium intake. The habit of consuming foods high in salt and high cholesterol in coastal communities has unwittingly become a risk factor for events hypertension. As a result of this lifestyle causes a tendency for hypertension to occur coastal area. The impact of urbanization and globalization is most evident in urban areas where unhealthy urban lifestyle is at risk of causing hypertension (Bokhour, et al., 2012; Hou, 2008; Peer et al., 2013; Perkovic, et al., 2007). City community has 
modern lifestyle followed by changes in the consumption patterns of foods containing high salt and fat. The pattern of consumption of these foods can affect body weight, which is usually accompanied by cigarette consumption, lack of physical activity and stress increase the risk of hypertension (Kohl 3 $3^{\text {rd }}$, et al., 2012). However, people's lifestyles the village shows the opposite. The traditional diet of the village people is high in protein, such as fermented milk which contains saponins and phenolic additives from plants can prevent hypertension by lowering blood cholesterol levels. In addition, active lifestyles such as more frequent walking every day is possible village communities are better protected from hypertension (Sack, et al., 2001). Therefore, it is likely there are differences between factors related to hypertension in coastal, urban areas with in the countryside. In addition, research related to non-communicable diseases usually associated with sedentary lifestyle in urban communities. While the community the coast and mountains have different lifestyles because of differences geographical conditions and types of livelihoods that have not been explored further. Based on cases of high prevalence of hypertension in Probolinggo and Surabaya, the author is interested in digging deeper about the relationship of quality of life style including diet and physical activity using the Healthy Lifestyle Index (HLI) for the incidence of hypertension as basic data that supports preventive efforts in preventing hypertension.

\section{METHODS}

\section{Study Design}

This type of research used descriptive research with analytic survey research methods using cross sectional study design.

\section{Setting}

This research was conducted at Probolinggo Regency (Supporting Public Health Center of Gili Ketapang and
Supporting Public Health Center of Wonotoro) and Surabaya City (Public Health Center of Kebonsari).

\section{Research Subject}

The population in this study were all patients who visited the Supporting Public Health Center of Gili Ketapang, Supporting Public Health Center of Wonotoro, and Public Health Center of Kebonsari. In period from June to July there were 90 people. The number of samples in the study were 30 people in the Coastal community, 30 people in the Mountain community and 30 people in the community urban by way of purposive sampling. Where is the purposive system sampling is a sampling technique by selecting samples among the population in accordance with what the researchers want, so that the sample can represent the characteristics previously known population. All patients visiting the Supporting Public Health Center of Gili Ketapang, Supporting Public Health Center of Wonotoro, and Public Health Center of Kebonsari were examined by blood pressure measurement and lifestyle assessment using the Tabung version of the Healthy Lifestyle Index (HLI) consisting of domains of diet quality, physical activity, smoking behavior, and BMI. Blood pressure measurements are carried out with a mercury sphygmomanometer and a stethoscope. The hypertension status is then determined based on JNC VII criteria. Inclusion criteria were patients with hypertension, aged 30 to 80 years, ability to give written consent, ability to complete interviews.

\section{Instruments}

Participants filled out questionnaires related to demographics, food intake, physical activity, smoking habits, alcohol consumption, and body mass index (BMI). Participants completed two food screenings to determine fruit and vegetable intake (Sheikh Iddenden, et al., 2008) and percent energy from fat (Reisner \& Thompson, 
2008). Physical activity including leisure activities, whether the activity is carried out outdoors or indoors, is assessed using a modified version of the Lifetime Total Physical Activity Questionnaire developed by Friedenreich and coworkers (1998), which documents the frequency, duration and duration of participation in the reported activity. Then add up the total duration (minutes/ week) for each activity in all activities for each individual to provide an estimate of the total physical activity per participant. During the on-site interview, lasting for about 10-15 minutes, we collected information about demographic characteristics (i.e., age, sex, smoking status). Then height and weight are measured to determine BMI. Each participant gets a score of one for each risk factor if they have never smoked; active regularly, i.e. $\geq 150$ minutes / week moderate intensity physical activity or $\geq 60$ minutes / week strong intensity physical activity; having a "normal" BMI < 25kg / $\mathrm{m} 2$, [no participants with low body weight (e.g., BMI < 18kg / m2)]; if not, participants receive a zero score for each of these factors. A diet quality score is built from two components - a combination of fruit and vegetable intake and energy percent from fat. Participants receive a score of one if they report $\geq 2.5$ cups of fruit and $\geq 2.5$ cups of vegetables per day ( $\geq 5$ servings per day) for the first component and if their energy percentage of fat is $\leq 30$ for the second component; otherwise they receive a zero score. Two diet scores were combined into a diet quality score, where participants with low fruit and vegetables and high percent energy from fat intake received a zero-diet quality score, while those who had high fruit/ vegetable intake and/ or low-fat intake received a diet quality score of one. The researchers then produced a combined healthy lifestyle index by summing the binary scores for each of the four components (smoking, physical activity, diet quality, and BMI). Researchers dichotomized the healthy lifestyle index, which ranged from 0 (the least healthy) to 5 (the healthiest), into the unhealthy (0-2) and healthy (3-5) categories.

\section{Data Analysis}

Data processing obtained from the results of this study is done through a process stage as follows: Editing, Coding, Data Tabulation, Cleaning. The results of this study were analyzed by two methods, namely univariate analysis and bivariate analysis. Univariate analysis using crosstabulation. Bivariate analysis using Chi-square test with significance level < 0.05. Statistical tests were performed using the SPSS program.

\section{Ethical Consideration}

This research has gone obtained permission from Nahdlatul Ulama University, Surabaya with license number 405/UNUSA/Adm-LPPM/V/2019. 


\section{RESULTS}

Characteristics of Respondents in Supporting Public Health Center of Gili Ketapang, Supporting Public Health Center of Wonotoro, and Public Health Center of Kebonsari

Table 1. Distribution of Characteristics of Respondents in Supporting Public Health Center of Gili Ketapang, Supporting Public Health Center of Wonotoro, and Public Health Center of Kebonsari on June-July, $2019(\mathrm{n}=90)$.

\begin{tabular}{|c|c|c|c|c|c|c|}
\hline \multirow[t]{2}{*}{$\begin{array}{c}\text { Characteristics of } \\
\text { Respondents }\end{array}$} & \multicolumn{2}{|c|}{$\begin{array}{l}\text { Mountain Community } \\
\text { (Supporting Public } \\
\text { Health Center of } \\
\text { Wonotoro) }\end{array}$} & \multicolumn{2}{|c|}{$\begin{array}{c}\text { Coastal Community } \\
\text { (Supporting Public } \\
\text { Health Center of Gili } \\
\text { Ketapang) }\end{array}$} & \multicolumn{2}{|c|}{$\begin{array}{c}\text { Urban Community } \\
\text { (Public Health Center } \\
\text { of Kebonsari) }\end{array}$} \\
\hline & $\mathbf{N}$ & $\%$ & $\mathbf{N}$ & $\%$ & $\mathbf{N}$ & $\%$ \\
\hline \multicolumn{7}{|l|}{ Aged (Years) } \\
\hline $40-54$ & 14 & 47 & 22 & 73 & 13 & 43 \\
\hline $55-64$ & 9 & 30 & 5 & 17 & 9 & 30 \\
\hline$\geq 65$ & 7 & 23 & 3 & 10 & 8 & 27 \\
\hline Total & 30 & 100 & 30 & 100 & 30 & 100 \\
\hline \multicolumn{7}{|l|}{ Gender } \\
\hline Male & 8 & 27 & 9 & 30 & 14 & 47 \\
\hline Female & 22 & 73 & 21 & 70 & 16 & 53 \\
\hline Total & 30 & 100 & 30 & 100 & 30 & 100 \\
\hline \multicolumn{7}{|l|}{ Dietary Habit } \\
\hline Healthy & 24 & 80 & 9 & 30 & 12 & 40 \\
\hline Unhealthy & 6 & 20 & 21 & 70 & 18 & 60 \\
\hline Total & 30 & 100 & 30 & 100 & 30 & 100 \\
\hline \multicolumn{7}{|l|}{ Smoking Activity } \\
\hline Smoking & 16 & 53 & 2 & 6.7 & 16 & 53 \\
\hline Not smoking & 14 & 47 & 28 & 93.3 & 14 & 47 \\
\hline Total & 30 & 100 & 30 & 100 & 30 & 100 \\
\hline \multicolumn{7}{|l|}{ Physical Activity } \\
\hline Active & 24 & 80 & 11 & 37 & 8 & 27 \\
\hline Not active & 6 & 20 & 19 & 63 & 22 & 73 \\
\hline Total & 30 & 100 & 30 & 100 & 30 & 100 \\
\hline \multicolumn{7}{|l|}{ Obesity } \\
\hline Obesity & 16 & 53 & 4 & 13 & 21 & 70 \\
\hline Not obese & 14 & 47 & 26 & 87 & 9 & 30 \\
\hline Total & 30 & 100 & 30 & 100 & 100 & 100 \\
\hline
\end{tabular}

Based on the results of this study above (table 1), it found that the most hypertension sufferers in the mountainous region at the age of 40-54 14 people in the year $(47 \%)$, the most in the coastal areas at the age of 40-54 years were 22people $(73 \%)$, in most urban areas at the age of 40 54 years as many as 13 people $(43 \%)$. The highest number of hypertension sufferers in the mountainous region there are 22 women $(73 \%)$ in the coastal area, most of them are female sex as many as 21 people (70\%), in most urban areas in the female sex as many as 16 people $(53 \%)$. The hypertension sufferers in the most mountainous regions have a pattern 24 healthy eating (80\%), most coastal areas have unhealthy eating patterns as many as 21 people (70\%), most urban areas have unhealthy eating patterns as many as 18 people $(60 \%)$. The hypertension sufferers in the most mountainous regions smoking habits as 
much as $16(53 \%)$, most coastal areas have no habit smoking as many as 28 people $(93.3 \%)$, in most urban areas have a habit smoking as many as 16 people $(53 \%)$. The hypertension sufferers in the mountainous region have the most active habits of as many as $24(80 \%)$, most coastal areas have the habit of inactivity as many as 19 people $(63 \% \%)$, in the most urban areas have the habit of inactivity as many as 22 people ( 73 $\%)$. The most people with hypertension in the mountainous region are 16 people $(53 \%)$, in the coastal areas the most are not obese as many as 26 people (87\%), in the urban areas the most obesity is 21 people $(70 \%)$.

Examination of the Relationship of Healthy Lifestyle to Occurrence of Hypertension in Supporting Public Health Center of Gili Ketapang, Supporting Public Health Center of Wonotoro, and Public Health Center of Kebonsari

Table 2. Examination of the Relationship of Healthy Lifestyle to Occurrence of Hypertension in Supporting Public Health Center of Gili Ketapang, Supporting Public Health Center of Wonotoro, and Public Health Center of Kebonsari by using Chi-Square Test $(n=90)$.

\begin{tabular}{|c|c|c|c|c|c|c|c|}
\hline \multirow{3}{*}{\multicolumn{2}{|c|}{ Categories of Lifestyle }} & \multicolumn{4}{|c|}{ Categories of Hypertension } & \multirow{3}{*}{ Total } & \multirow{3}{*}{$p$-value } \\
\hline & & \multicolumn{2}{|c|}{$\begin{array}{c}\text { Mild } \\
\text { Hypertension }\end{array}$} & \multicolumn{2}{|c|}{$\begin{array}{l}\text { Moderate and } \\
\text { Severe } \\
\text { Hypertension }\end{array}$} & & \\
\hline & & $\mathbf{N}$ & $\%$ & $\mathbf{N}$ & $\%$ & & \\
\hline \multicolumn{8}{|c|}{ Mountain Community (Supporting Public Health Center of Wonotoro) } \\
\hline \multirow[t]{2}{*}{ Dietary Habit } & Yes & 21 & 70 & 3 & 10 & 24 & \multirow[t]{2}{*}{0.063} \\
\hline & No & 1 & 3 & 5 & 17 & 6 & \\
\hline Total & & 22 & 73 & 8 & 27 & 30 & \multirow{3}{*}{0.000} \\
\hline \multirow[t]{2}{*}{ Smoking Activity } & Yes & 2 & 7 & 14 & 47 & 16 & \\
\hline & No & 13 & 43 & 1 & 3 & 14 & \\
\hline Total & & 15 & 50 & 15 & 50 & 100 & \multirow{3}{*}{0.000} \\
\hline \multirow[t]{2}{*}{ Physical Activity } & Yes & 20 & 67 & 4 & 13 & 24 & \\
\hline & No & 0 & 0 & 6 & 20 & 6 & \\
\hline \multirow{3}{*}{ Obesity } & & 20 & 67 & 10 & 33 & 30 & \multirow{4}{*}{0.004} \\
\hline & Yes & 7 & 23 & 9 & 30 & 16 & \\
\hline & No & 11 & 37 & 3 & 10 & 14 & \\
\hline Total & & 18 & 60 & 12 & 40 & 30 & \\
\hline \multicolumn{8}{|c|}{ Coastal Community (Supporting Public Health Center of Gili Ketapang) } \\
\hline \multirow[t]{2}{*}{ Dietary Habit } & Yes & 9 & 30 & 0 & 0 & 9 & \multirow[t]{2}{*}{0.041} \\
\hline & No & 3 & 10 & 18 & 60 & 21 & \\
\hline \multicolumn{2}{|l|}{ Total } & 12 & 40 & 18 & 60 & 30 & \multirow{3}{*}{0.180} \\
\hline \multirow[t]{2}{*}{ Smoking Activity } & Yes & 20 & 67 & 8 & 27 & 28 & \\
\hline & No & 0 & 0 & 2 & 6 & 2 & \\
\hline \multicolumn{2}{|l|}{ Total } & 20 & 67 & 10 & 33 & 30 & \multirow{3}{*}{0.030} \\
\hline \multirow[t]{2}{*}{ Physical Activity } & Yes & 8 & 27 & 3 & 10 & 11 & \\
\hline & No & 3 & 10 & 16 & 53 & 19 & \\
\hline \multirow{3}{*}{ Obesity } & & 11 & 37 & 19 & 63 & 30 & \multirow{4}{*}{0.518} \\
\hline & Yes & 0 & 0 & 4 & 13 & 4 & \\
\hline & No & 20 & 67 & 6 & 20 & 26 & \\
\hline Total & & 20 & 67 & 10 & 33 & 30 & \\
\hline \multicolumn{7}{|c|}{ Urban Community (Public Health Center of Kebonsari) } & \multirow{3}{*}{0.000} \\
\hline Dietary Habit & Yes & 5 & 17 & 7 & 23 & 12 & \\
\hline & No & 6 & 20 & 12 & 40 & 18 & \\
\hline
\end{tabular}




\begin{tabular}{|c|c|c|c|c|c|c|c|}
\hline Total & & 11 & 37 & 19 & 63 & 30 & \\
\hline \multirow[t]{2}{*}{ Smoking Activity } & Yes & 11 & 36 & 5 & 17 & 16 & \multirow{2}{*}{0.014} \\
\hline & No & 8 & 27 & 6 & 20 & 14 & \\
\hline \multicolumn{2}{|l|}{ Total } & 19 & 63 & 11 & 37 & 30 & \multirow{3}{*}{0.003} \\
\hline \multirow[t]{2}{*}{ Physical Activity } & Yes & 10 & 33 & 12 & 40 & 22 & \\
\hline & No & 6 & 20 & 2 & 7 & 8 & \\
\hline \multirow[t]{3}{*}{ Total } & & 16 & 53 & 14 & 47 & 30 & \multirow{4}{*}{0.043} \\
\hline & Yes & 5 & 17 & 16 & 53 & 21 & \\
\hline & No & 5 & 17 & 4 & 13 & 9 & \\
\hline Total & & 10 & 34 & 20 & 66 & 30 & \\
\hline
\end{tabular}

Based on the data in table 2, it is found that several categories of lifestyle in the three community groups that serve as respondents have a significant relationship with the occurrence of hypertension.

In mountain communities, there is a significant relationship between smoking activity, physical activity, and obesity with the occurrence of hypertension ( $p=0.000$, $p=0.000, p=0.004$, respectively). In mountain communities, only dietary habits that are not related to the occurrence of hypertension $(p=0.063)$.

In coastal communities, there is a significant relationship between dietary habit $(p=0.041)$ and physical activity ( $p=$ 0.030 ) with the occurrence of hypertension. While smoking activity $(p=0.180)$ and obesity $(p=0.518)$ are not associated with the occurrence of hypertension.

In urban communities, the results of the study found that dietary habit, smoking activity, physical activity, and obesity had significant relationship with the occurrence of hypertension $(p=0.000, p=0.014, p=$ $0.003, p=0.043$, respectively).

\section{DISCUSSION}

Relationship between HLI scores with hypertension in the mountain community in Wonotoro village. From the results of research in the mountain community of Wonotoro Village in Probolinggo 2019, hypertension is caused due to smoking and obesity. Subjects in the mountains of the village of Wonotoro in the Bromo mountain area have a smoking habit both for men and women because of the cold weather so that the way to warm their bodies is by smoking cigarette smoke. The results of this study are in line with research conducted by Suoth, Bidjuni, and Malara (2014) saying that lifestyle greatly influences the occurrence of hypertension. As for lifestyle, the variables in this study are food consumption, smoking, stress and physical activity. According to medical science, cigarettes contain approximately 4000 chemicals, including nicotine, tar, carbon monoxide and hydrogen cyanide. One of the cigarette contents that greatly influences blood pressure is nicotine. The effect of nicotine causes stimulation of the hormone catecholamine (adrenaline) which is stimulating the heart and blood pressure. The heart is not given a chance to rest and blood pressure will increase, resulting in hypertension. Nicotine activates platelets with the result of thrombose adhesion (clotting) to the walls of blood vessels. Nicotine, $\mathrm{CO}$ and other ingredients in cigarette smoke have been shown to damage endothelial walls (walls in blood vessels), and facilitate blood clotting. As a result of clotting (platelets) will damage peripheral blood vessels (Sitepoe, 1997). By smoking a cigarette, it will have a major influence on the increase in hypertension. This can be caused by the $\mathrm{CO}$ gas produced by cigarette smoke can cause blood vessels "Kramp" so that blood pressure rises, the blood vessel walls become torn.

Obesity in patients with hypertension in mountain communities has a habit of consuming a lot of meat, because the tradition of the Tengger tribal ceremonies 
every religious ceremony always consumes beef which must be spent with family and close relatives. The results of the analysis conducted by previous researchers showed that beef has higher total fat, cholesterol, and saturated fat compared to goat meat (Noor, 2008). According to Appleby et al the vegetarian group had lower blood pressure than the group that consumed meat because of their higher magnesium intake. In an epidemiological study it is known that lack of potassium, calcium, and magnesium intake can cause an increase in blood pressure, for normal needs of potassium per day $80 \mathrm{mEq}$ (3 grams), calcium about one gram per day, and for magnesium $4.5 \mathrm{mg} /$ $\mathrm{kg}$ weight agency (Almatsier, 2008). Meat contains a lot of protein, meanwhile consuming food especially protein can cause specific dynamic action response which depends on the amount of protein consumed (Scor, 2009). Protein can increase the body's metabolism by $30 \%$ starting from 60 minutes to three or 12 hours afterwards. This increase in body metabolism will be followed by an increase in systemic blood flow which allows an increase in blood pressure. (Guyton, 2007).

Relationship between HLI Score with the incidence of Hypertension in the coastal communities of Gili Ketapang. From the results of research in the coastal communities of Gili Ketapang in Probolinggo 2019, hypertension is caused due to diet and inactivity. Subjects on the coast of Gili Ketapang have a habit of consuming a lot of shrimp, squid and sea fish because it is the main food source in the Gili Ketapang region. And these foods are also made crackers, salted fish and boiled which contain a lot of salt. In the Gili Ketapang region, the people rarely consume vegetables and fruits because the coastal area has no fruit plants and vegetable plants are very rarely found, because vegetables and fruit must be imported from the city of Probolinggo. High sodium intake affects the onset of hypertension through the mechanism of increasing plasma volume, cardiac output, and blood pressure. Excessive intake will increase fluid from cells, where water will move towards electrolyte solutions that have higher concentrations. This results in an increase in blood plasma volume and will increase cardiac output, thereby increasing blood pressure. In addition, high intake of sodium can reduce the diameter of the arteries, so that the heart pumps harder to encourage increased blood volume through narrow spaces (Lestari, 2010).

In addition, high seafood consumption also plays a role in the tendency of hypertension in coastal areas. One of the risk factors for hypertension is fat content in the body as stated that hypercholesterolemia is a risk factor for hypertension (Dedullah et al., 2015). Meanwhile, the cholesterol content of freshwater fish tissue is generally lower than that of sea fish (Saidin, 2000). The habit of consuming foods high in salt and high cholesterol in coastal communities has unwittingly become a risk factor for hypertension. As a result of this lifestyle causes a tendency for hypertension in the coastal areas (Rusliafa, 2014).

Coastal communities almost never exercise, because the island is small and very densely populated and sports are not a habit of these communities. Gili Ketapang residents' daily habits only sail and women only do activities as housewives. Lack of physical activity can increase the risk of suffering from hypertension because it increases the risk of being overweight. People who are not active too tend to have a higher heart rate so that the heart muscle must work harder with each contraction. The harder and often the heart muscle has to pump, the greater the pressure placed on the arteries (Sundari, 2013).

Relationship between HLI scores with the incidence of hypertension in urban communities in Kebonsari. From the results of research in the urban area of Surabaya City Kebonsari 2019, hypertension is 
caused due to diet, smoking, lack of activity and obesity.

Subjects in urban Kebonsari have a habit of buying cooked or processed dishes because no one is cooking, where cooked dishes are processed using a lot of flavoring and preservatives. Foods that contain high sodium such as table salt, salted fish, boiled fish, instant noodles, flavoring. The effect of sodium intake on high blood pressure occurs through an increase in plasma volume and blood pressure. Sodium is the main cation in extracellular fluid which plays an important role in maintaining plasma and extracellular volume, acid base balance and also neuromuscular. High sodium intake can cause the concentration of sodium in the extracellular fluid to increase so as to normalize intracellular fluid drawn out and result in increased blood volume and an impact on increasing blood pressure (Astawan, 2007).

Most of the community's daily activities are staying at home enjoying retirement, for only a part of the sport who participated in sports when the integrated service post of elderly but not routinely to follow it. Relaxed behavior characterized by higher calorie intake and lack of physical activity are risk factors for heart disease, which is usually preceded by increased blood pressure (Hou, 2008). Relaxed behavior that is illustrated by the ease of access, lack of physical activity, coupled with the liveliness of fast food, eating less fibrous foods such as fruits and vegetables, smoking habits, and drinking alcoholic beverages are risk factors for increasing blood pressure. It is also a reflection of life in urban areas (Steffen et al., 2006).

Existing subjects in the city have a smoking habit because the habit is still actively working and until now it is still difficult to eliminate smoking. In addition, because there are no more routine activities, most of them escape by smoking. And they assume smoking does not cause disease. Based on Schmitt's research, smoking behavior persists not only because of addiction. Certain assumptions that older people have about cigarettes (cigarettes are harmless, the enjoyment of life is also an important factor in maintaining smoking behavior. Smoking can increase the workload of the heart and increase blood pressure. According to research, it is revealed that smoking can increase blood pressure. Nicotine which contained in cigarettes is very dangerous to health, because nicotine can increase blood clots in blood vessels and can cause calcification in the walls of blood vessels. Nicotine is toxic to nerve tissue that causes an increase in blood pressure both systolic and diastolic, heart rate increases, heart muscle contractions such as forced, increased $\mathrm{O} 2$ use, increased coronary blood flow and vasoconstriction in peripheral arteries (Gray, et al. 2005).

Obesity in patients with hypertension in urban communities has a habit of consuming a lot of fat in fried foods, ready meals and lack of activity. The risk of developing hypertension with more body weight is 2.3 times more likely than that normal weight and thin. Schmieder's (1993) research revealed that respondents with more weight will accumulate fat tissue, which can cause increased blood vessel resistance in increasing the work of the heart to be able to pump blood throughout the body. In Rose's study of the American population, respondents in the 20-39 age group who were overweight, had twice the chance compared to normal weight, and had three times the chance of getting hypertension when compared to thin people. Whereas in the age group 4064 years, respondents with more weight have a 50 percent chance of suffering from hypertension compared to normal body weight

\section{CONCLUSION}

The findings of this study indicate that lifestyle is very influential on the incidence of hypertension, namely unhealthy eating 
patterns, smoking, lack of activity and obesity. behavior modification is very important in preventing the elderly in the mountains, the coast and cities from hypertension. Target the elderly with the promotion and prevention of a healthy lifestyle to increase awareness of the importance of risk factors for hypertension.

\section{SUGGESTIONS}

Based on these results, the government must pay more attention to PTM prevention programs by creating promotive and preventive programs so that they can be implemented consistently. Develop existing promotive and preventive models in accordance with local conditions and local culture. Increase education and promotion in an effort to reduce sedentary life, stop smoking culture and excessive calorie intake by increasing efforts.

\section{ACKNOWLEDGMENT}

The author would like to thank the Head of the National Research and Development Agency for providing the opportunity to carry out analyzes in mountainous, coastal and urban areas. To Nahdlatul Ulama University, Surabaya, we thank you for the funding provided so that this research can be carried out well. To the data team that has helped in the integration of several data sources making it easier to do the analysis.

\section{DECLARATION OF CONFLICTING INTEREST}

None.

\section{FUNDING}

The research funding was obtained from research grants at Nahdlatul Ulama University, Surabaya.

\section{AUTHOR CONTRIBUTION}

Iis Noventi: As the lead researcher and compiles the results of research in the form of scientific articles.
Yanis Kartini: As a member of the researcher and helps the process of preparing scientific articles.

\section{ORCID}

Iis Noventi

None.

Yanis Kartini

None.

\section{REFERENCES}

Addo, J., Smeeth, L., \& Leon, D. A. (2007). Hypertension in sub-saharan Africa: a systematic review. Hypertension, 50(6), 1012-1018.

Arif, D., Rusnoto, R., \& Hartinah, D. (2013). Faktor-Faktor Yang Berhubungan Dengan Kejadian Hipertensi Pada Lansia Di Pusling Desa Klumpit Upt Puskesmas Gribig Kabupaten Kudus. Jurnal Ilmu Keperawatan dan Kebidanan, 4(2).

Astawan, M. (2007). Cegah Hipertensi dengan Pola Makan, [serial Online]. Retrieved from http://www.depkes.go.id on January 29, 2017.

Balai Informasi Teknologi LIPI. (2009). Hipertensi. Jakarta: LIPI.

Balitbang Kemenkes RI. (2013). Riset Kesehatan Dasar; RISKESDAS. Jakarta: Balitbang Kemenkes RI.

Bokhour, B. G., Cohn, E. S., Cortés, D. E., Solomon, J. L., Fix, G. M., Elwy, A. R., ... \& Borzecki, A. M. (2012). The role of patients' explanatory models and daily-lived experience in hypertension selfmanagement. Journal of general internal medicine, 27(12), 1626-1634.

Departemen Kesehatan RI. (2006). "Survei Kesehatan Rumah Tangga (SKRT) 2004, Volume 3, Sudut Pandang Masyarakat mengenai Status, Cakupan, Ketanggapan, dan Sistem Pelayanan Kesehatan”. Jakarta: Badan Litbangkes Depkes RI. 
Departemen Kesehatan RI. (2007). Laporan Hasil Riset Kesehatan Dasar 2007. Jakarta: Badan Penelitian dan Pengembangan Kesehatan Departemen Kesehatan Repulik Indonesia.

Dedullah R. F., Malonda N. S., Joseph W. B. S. (2015). Hubungan antara faktor risiko hipertensi dengan kejadian hipertensi pada masyarakat di kelurahan motoboi kecil kecamatan kotamobagu selatan kota kotamobagu. Jurnal Kesehatan Masyarakat, 1(3), 155-63.

Ekowati, R., \& Sulistyowati, T. (2009). Prevalensi hipertensi dan determinannya di Indonesia. Majalah Kedokteran Indonesia, 59(12), 36.

Feryadi, R., Sulastri, D., \& Kadri, H. (2014). Hubungan kadar profil lipid dengan kejadian hipertensi pada masyarakat etnik Minangkabau di kota Padang tahun 2012. Jurnal Kesehatan Andalas, 3(2), 206-11.

Franklin, S. S., Khan, S. A., Wong, N. D., Larson, M. G., \& Levy, D. (1999). Is pulse pressure useful in predicting risk for coronary heart disease? The Framingham Heart Study. Circulation, 100(4), 354-360.

Friedenreich, C. M., Courneya, K. S., \& Bryant, H. E. (1998). The lifetime total physical activity questionnaire: development and reliability. Medicine and science in sports and exercise, 30(2), 266-274.

Gray, H. H., Dawkins, K. D., Morgan, J. M., \& Simpson, I. A. (2005). Lacture Notes: Kardiologi. Edisi keempat. Diterjemahkan. Jakarta. Erlangga.

Hamer, M., Batty, G. D., Stamatakis, E., \& Kivimaki, M. (2010). The combined influence of hypertension and common mental disorder on all-cause and cardiovascular disease mortality. Journal of hypertension, 28(12), 2401-2406.
Hou, X. (2008). Urban-rural disparity of overweight, hypertension, undiagnosed hypertension, and untreated hypertension in China. Asia Pacific Journal of Public Health, 20(2), 159-169.

Kohl 3rd, H. W., Craig, C. L., Lambert, E. V., Inoue, S., Alkandari, J. R., Leetongin, G., ... \& Lancet Physical Activity Series Working Group. (2012). The pandemic of physical inactivity: global action for public health. The lancet, 380(9838), 294305.

Kusuma, Y. S., Babu, B. V., \& Naidu, J. M. (2004). Prevalence of hypertension in some cross-cultural populations of Visakhapatnam district, South India. Ethnicity and Disease, 14(2), 250-259.

Lestari, D., \& Lelyana, R. (2010). Hubungan Asupan Kalium, Kalsium, Magnesium, dan Natrium, Indeks Massa Tubuh, serta Aktifitas Fisik dengan Kejadian Hipertensi pada Wanita Usia 30-40 Tahun (Doctoral dissertation, Program Studi Ilmu Gizi).

Mannan H., Wahiduddin, Rismayanti. (2012). Faktor risiko kejadian hipertensi di wilayah kerja puskesmas bangkala kabupaten jeneponto tahun 2012. MKMI, 1, 1-13.

Marmot, M. G., Elliott, P., Shipley, M. J., Dyer, A. R., Ueshima, H. U., Beevers, D. G., ... \& Stamler, J. (1994). Alcohol and blood pressure: the INTERSALT study. Bmj, 308(6939), 1263-1267.

Musinguzi, G., \& Nuwaha, F. (2013). Prevalence, awareness and control of hypertension in Uganda. PloS one, 8(4), e62236.

Peer, S., Knockaert, J., Koster, P., Tseng, Y. Y., \& Verhoef, E. T. (2013). Doorto-door travel times in RP departure time choice models: An approximation method using GPS data. Transportation Research Part B: Methodological, 58, 134-150. 
Perkovic, V., Huxley, R., Wu, Y., Prabhakaran, D., \& MacMahon, S. (2007). The burden of blood pressurerelated disease: a neglected priority for global health. Hypertension, 50(6), 991-997.

Pradono, J. (2010). Faktor-faktor yang memengaruhi terjadinya hipertensi di daerah perkotaan (analisis data riskesdas 2007). Gizi Indonesia, 33(1), 59-66.

Reisner, R., \& Thompson, D. (2008). The diet industry: A big fat lie. Bloomberg Businessweek.

Rusliafa, J., Amiruddin, R., \& Noor, N. B. (2014). Komparatif kejadian hipertensipada wilayah pesisirpantai dan pegunungan di kota kendari tahun 2014. MKMI, 1, 1-13.

Sacks, F. M., Svetkey, L. P., Vollmer, W. M., Appel, L. J., Bray, G. A., Harsha, D., ... \& Karanja, N. (2001). Effects on blood pressure of reduced dietary sodium and the Dietary Approaches to Stop Hypertension (DASH) diet. New England journal of medicine, 344(1), 3-10.

Saidin, M. (1999). Kandungan kolesterol dalam berbagai bahan makanan hewani. Buletin Penelitian Kesehatan, 27(2 Jun).

Saputra, O., \& Anam, K. (2016). Gaya hidup sebagai faktor risiko hipertensi pada masyarakat pesisir pantai. Jurnal Majority, 5(3), 118-123.

Sarimawar, D., dkk. (1992). Trend Pola Penyebab Kematian (Analisis Survei Kesehatan Rumah Tangga 19921997). Jakarta: Balitbangkes Depkes RI.

Schmieder, R. E., \& Messerli, F. H. (1993). Does obesity influence early target organ damage in hypertensive patients?. Circulation, 87(5), 14821488

Schmitt, E. M., Tsoh, J. Y., Dowling, G. A., \& Hall, S. M. (2005). Older adults' and case managers' perceptions of smoking and smoking cessation. Journal of aging and health, 17(6), 717-733.

Sheikh Iddenden, R., Porter, M., Alabady, K., Greene, T., \& Taylor, A. (2008). Health and lifestyle survey, Hull 2007.

Sigarlaki, H. J. (2006). Karakteristik dan faktor berhubungan dengan hipertensi di desa bocor, kecamatan bulus pesantren, kabupaten kebumen, jawa tengah, tahun 2006. Makara, Kesehatan, 10(2), 78-88.

Sitepoe, M. (1997). Usaha mencegah bahaya merokok. Jakarta: Gramedia, 21-5.

Solikhah, S., Djannah, S. N., \& Yeni, Y. (2010). Faktor faktor yang Berhubungan dengan Kejadian Hipertensi pada Wanita Usia Subur di Puskesmas Umbulharjo I Yogyakarta Tahun 2009. Kes Mas: Jurnal Fakultas Kesehatan Masyarakat Universitas Ahmad Daulan, 4(2).

Stamler, R., Stamler, J., Riedlinger, W. F., Algera, G., \& Roberts, R. H. (1978). Weight and blood pressure: findings in hypertension screening of 1 million Americans. Jama, 240(15), $\quad$ 16071610.

Steffen, P. R., Smith, T. B., Larson, M., \& Butler, L. (2006). Acculturation to Western society as a risk factor for high blood pressure: a meta-analytic review. Psychosomatic medicine, 68(3), 386-397.

Sundari, S., Wahono, D., \& Widodo, M. A. (2013). Faktor Risiko Non Genetik dan Polimorfisme Promoter RegionGen CYP11B2Varian $\mathrm{T} \quad(-344) \quad \mathrm{C}$ Aldosterone Synthasepada Pasien Hipertensi Esensial di Wilayah Pantai dan Pegunungan. Jurnal Kedokteran Brawijaya, 27(3), 169-177.

Suoth, M., Bidjuni, H., \& Malara, R. (2014). Hubungan gaya hidup dengan kejadian hipertensi di puskesmas kolongan kecamatan kalawat kabupaten minahasa utara. Jurnal Keperawatan, 2(1). 
Sutangi H, Winantri. (2013). Faktor yang berhubungan dengan kejadian hipertensi pada lansia di pobindu desa sukaurip kecamatan balongan indramayu. Jurnal UNWIR, 1, 1-8.

Tabung, F. K., Steck, S. E., Burch, J. B., Chen, C. F., Zhang, H., Hurley, T. G., ... \& Lloyd, S. C. (2015). A healthy lifestyle index is associated with reduced risk of colorectal adenomatous polyps among non-users of non-steroidal anti-inflammatory drugs. The journal of primary prevention, 36(1), 21-31.

World Health Organization. (2011). WHO report on the global tobacco epidemic, 2011: warning about the dangers of tobacco. Geneva: World Health Organization.

World Health Organization. (2013). Global tuberculosis report 2013. World Health Organization.

Cite This Article As: Noventi, I., \& Kartini, Y. The Relationship of Healthy Lifestyle Index (HLI) to the Occurrence of Hypertension in Mountains, Coastal, and Urban Communities. Nurse and Health: Jurnal Keperawatan 2019; 8(2): 140-152. 